\title{
Chiral manganese and iron complexes of binaphthyl Schiff bases: syntheses, crystal structures and asymmetric epoxidation of alkenes
}

\author{
M ing- $C$ huan $C$ heng, ${ }^{a} \mathrm{M}$ ichael $\mathrm{C}$ hi-W ang $\mathrm{C}$ han, ${ }^{\mathrm{a}}$ Shie-M ing Peng, ${ }^{\mathrm{b}} \mathrm{K}$ ung-K ai $\mathrm{C}$ heung ${ }^{\mathrm{a}}$ and \\ Chi-M ing $\mathrm{Che}^{* \text {, a }}$
}

a D epartment of Chemistry, The U niversity of $\mathrm{H}$ ong Kong, Pokfulam R oad, $\mathrm{H}$ ong Kong

${ }^{b}$ D epartment of Chemistry, National Taiwan U niversity, Taipei, Taiwan

\begin{abstract}
The chiral binaphthyl Schiff-base manganese complexes [M $n L(X)]\left[H_{2} L=2,2^{\prime}\right.$-bis(3- $R^{1}-5-R^{2}$-2-hydroxybenzylideneimino)-1, $1^{\prime}$-binaphthyl; $\mathrm{R}^{1}=\mathrm{R}^{2}=\mathrm{Cl}, \mathrm{X}=\mathrm{O}_{2} \mathrm{CM}$ e $1 ; \mathrm{R}^{1}=\mathrm{Et}, \mathrm{R}^{2}=\mathrm{N} \mathrm{O}_{2}, \mathrm{X}=\mathrm{O}_{2} \mathrm{CM}$ e 2; $\mathrm{R}^{1}=\mathrm{R}^{2}=\mathrm{Cl}$, $\mathrm{X}=\mathrm{acac}$ (acetylacetonate) 3] and an iron analogue $\left[\mathrm{FeL}\right.$ (acac)] $\mathbf{4}\left(\mathrm{R}^{1}=\mathrm{R}^{2}=\mathrm{Cl}\right.$ ) have been prepared. The crystal structures of the racemic forms of $3 \cdot \mathrm{CH}_{2} \mathrm{Cl}_{2}$ and $\mathbf{4} \cdot 2 \mathrm{H}_{2} \mathrm{O}$ exhibit non-planar cis- $\beta$ configurations with dihedral angles of 85.5 and $72.1^{\circ}$ respectively between the two naphthalene rings. Complexes (R)-1 to 3 are active catalysts for the asymmetric epoxidation of alkenes by PhI 0 . The oxidation of cis- $\beta$-methylstyrene by (R )- 2 in toluene at $-20{ }^{\circ} \mathrm{C}$ gave an enantiomeric excess of $76 \%$.
\end{abstract}

\begin{abstract}
The search for chiral complexes which can catalyse asymmetric oxidation has continued to attract considerable interest. ${ }^{1}$ Recent results in asymmetric epoxidation of unfunctionalised alkenes have been achieved by Jacobsen and $\mathrm{K}$ atsuki ${ }^{2}$ using chiral Schiff-base manganese complexes based on optically active 1,2-diamines. H owever, the binaphthyl moiety, which has been effectively deployed in other asymmetric catalysis reactions, ${ }^{3}$ has rarely been incorporated into the Schiff base for mediating asymmetric oxidation. We recently reported that the in situ $\mathrm{Mn}\left(\mathrm{O}_{2} \mathrm{CMe}\right)_{3}+(\mathrm{S})-\mathrm{H}_{2} \mathrm{~L}$ systems $\left[\mathrm{H}_{2} \mathrm{~L}=2,2^{\prime}\right.$-bis $\left(3-\mathrm{R}^{1}\right.$ 5- $\mathrm{R}^{2}$-2-hydroxybenzylideneimino)-1, $1^{\prime}$-binaphthyl, $\mathrm{R}^{1}=\mathrm{Cl}, \mathrm{H}$ or alkyl; $\mathrm{R}^{2}=\mathrm{Cl}, \mathrm{N} \mathrm{O}_{2}$ or $\mathrm{M}$ e] are effective catalysts for asymmetric epoxidation of alkenes by $\mathrm{Phl} \mathrm{0.4} \mathrm{N}$ evertheless, there are few examples of complexes containing the binaphthyl Schiffbase ligand ${ }^{5}$ and to our knowledge the only published crystal structure is the copper(II) complex where $\mathrm{R}^{1}=\mathrm{R}^{2}=\mathrm{Cl}^{4}{ }^{4}$ We now report the successful synthesis of monomeric chiral manganese(III) and iron(III) binaphthyl Schiff-base complexes, and asymmetric catalysis results which show improved enantioselectivity. Crystal structures of complexes in racemic forms have been determined.
\end{abstract}

\section{Experimental}

F ull instrumentation details and preparation of the chiral and racemic forms of the Schiff base have been given. ${ }^{4}$ The compounds $\mathrm{M} \mathrm{n}^{\prime \prime \prime}\left(\mathrm{O}_{2} \mathrm{CM} \mathrm{e}\right)_{3} \cdot 2 \mathrm{H}_{2} \mathrm{O}$ (Aldrich) and [ $\left.\mathrm{Fe}^{\prime \prime \prime}(\mathrm{acac})_{3}\right]$ (acac = acetylacetonate) (Strem) were dried in vacuo before use;

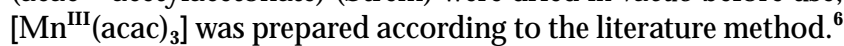
lodosylbenzene was prepared by hydrolysis of iodobenzene diacetate (Aldrich) in $\mathrm{NaOH}$ solution. Solvents for catalytic epoxidation were purified according to standard procedures. ${ }^{7}$ All alkene substrates used for catalytic epoxidation were from A Idrich and F luka and purified either by vacuum distillation or by passing through activated alumina. cis- $\beta-M$ ethylstyrene was prepared by hydrogenation of 1-phenylprop-1-yne (Aldrich) using Lindler catalyst. ${ }^{8}$ Racemic styrene oxide was obtained from F luka and distilled before use; (R )-(-) styrene oxide from Aldrich was used without further purification. All other epoxides required for determination of product yield and enantiomeric excess (e.e.) were independently prepared from the corresponding alkene and m-chloroperoxybenzoic acid in dichloromethane. $^{9}$

\section{Syntheses}

[M n'l' ${ }^{1}\left(\mathrm{O}_{2} \mathrm{CM}\right.$ e)] 1. A mixture of $\mathrm{H}_{2} \mathrm{~L}^{1}(0.5 \mathrm{~g}, 0.8 \mathrm{mmol})$

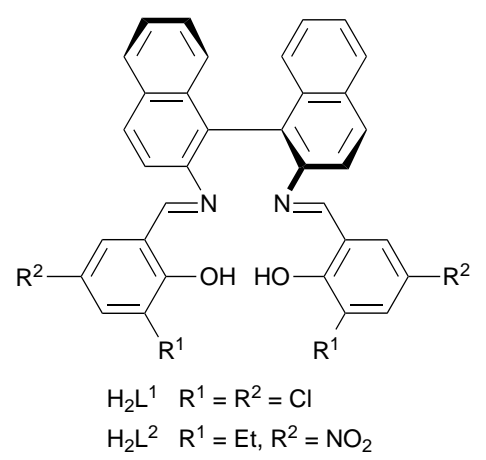

and $\mathrm{M} \mathrm{n}\left(\mathrm{O}_{2} \mathrm{CM} \mathrm{e}\right)_{3} \cdot 2 \mathrm{H}_{2} \mathrm{O}(0.21 \mathrm{~g}, 0.8 \mathrm{mmol})$ in acetonitrile ( 30 $\mathrm{cm}^{3}$ ) was heated at $60{ }^{\circ} \mathrm{C}$ for $30 \mathrm{~min}$. The solvent was removed in vacuo. The residue was dissolved in dichloromethane $\left(10 \mathrm{~cm}^{3}\right)$ and then filtered. Addition of $n$-hexane yielded a green solid. Chiral complexes were prepared by the same method using optically active ligands. Y ield $0.44 \mathrm{~g}, 74 \%$ (Found: $\mathrm{C}, 58.1 ; \mathrm{H}$, 3.1; N, 3.8. $\mathrm{C}_{36} \mathrm{H}_{21} \mathrm{Cl}_{4} \mathrm{M} \mathrm{nN}_{2} \mathrm{O}_{4}$ requires $\mathrm{C}$, 58.25; $\mathrm{H}, 2.85 ; \mathrm{N}$, $3.8 \%) ; \lambda_{\max }\left(\mathrm{CH}_{3} \mathrm{CN}\right) / \mathrm{nm} 222$ ( $\varepsilon$ 87820), 274 (51740), 317 (19590) and $391\left(14180 \mathrm{dm}^{3} \mathrm{~mol}^{-1} \mathrm{~cm}^{-1}\right) ; \tilde{v}(\mathrm{~K} \mathrm{Br}) / \mathrm{cm}^{-1} 1602$ $(\mathrm{C}=\mathrm{N})$ and $1421\left(\mathrm{O}_{2} \mathrm{CM} \mathrm{e}\right) ; \mathrm{m} / \mathrm{z} 683\left(\mathrm{M}-\mathrm{O}_{2} \mathrm{CM} \mathrm{e}\right)$.

[M n "'I ${ }^{2}\left(\mathbf{O}_{2} \mathbf{C}\right.$ e)] 2. The procedure was the same as for complex 1 using $\mathrm{Mn}\left(\mathrm{O}_{2} \mathrm{CM} \mathrm{e}\right)_{3} \cdot 2 \mathrm{H}_{2} \mathrm{O}(0.21 \mathrm{~g}, 0.8 \mathrm{mmol})$ and $\mathrm{H}_{2} \mathrm{~L}^{2}(0.5 \mathrm{~g}, 0.8 \mathrm{mmol})$. Chiral complexes were prepared using optically active ligands. $\mathrm{Y}$ ield $0.49 \mathrm{~g}, 81 \%$ (Found: $\mathrm{C}$, 66.7; $\mathrm{H}$, 4.5; $\mathrm{N}$, 7.7. $\mathrm{C}_{40} \mathrm{H}_{31} \mathrm{M} \mathrm{nN}_{4} \mathrm{O}_{8}$ requires $\mathrm{C}, 66.85 ; \mathrm{H}, 4.45$; $\mathrm{N}, 7.8 \%) ; \lambda_{\max }\left(\mathrm{CH}_{3} \mathrm{CN}\right) / \mathrm{nm} 242$ (ع 80560), 274 (54620), 317 (19590), 386 (14190 dm $\left.\mathrm{dmol}^{-1} \mathrm{~cm}^{-1}\right) ; \tilde{v}(\mathrm{~K} \mathrm{Br}) / \mathrm{cm}^{-1} 1593$ (C=N ), $1420\left(\mathrm{O}_{2} \mathrm{CM} \mathrm{e}\right)$ and $1315\left(\mathrm{~N} \mathrm{O}_{2}\right)$.

[M n"'L ${ }^{1}$ (acac)] 3. A mixture of $\mathrm{H}_{2} \mathrm{~L}^{1}(0.3 \mathrm{~g}, 0.5 \mathrm{mmol})$ and [M n(acac) $)_{3}$ ( $\left.0.18 \mathrm{~g}, 0.5 \mathrm{mmol}\right)$ in acetonitrile $\left(30 \mathrm{~cm}^{3}\right)$ was refluxed for $4 \mathrm{~h}$. The solution was evaporated to dryness and then dissolved in dichloromethane. $U$ pon addition of $n$-hexane a green solid was obtained. Chiral complexes were prepared by the same method using optically active ligands. $Y$ ield $0.33 \mathrm{~g}$, 85\% (Found: $\mathrm{C}, 59.6 ; \mathrm{H}, 3.5 ; \mathrm{N}, 3.7 . \mathrm{C}_{39} \mathrm{H}_{25} \mathrm{Cl}_{4} \mathrm{M} \mathrm{nN}{ }_{2} \mathrm{O}_{4}$ requires C, 59.9; $\mathrm{H}, 3.2 ; \mathrm{N}, 3.6 \%) ; \lambda_{\max }\left(\mathrm{CH}_{2} \mathrm{Cl}_{2}\right) / \mathrm{nm} 220$ ( $\left.\varepsilon 104870\right), 273$ (74720), 320 (26490) and 389 (15860 $\left.\mathrm{dm}^{3} \mathrm{~mol}^{-1} \mathrm{~cm}^{-1}\right) ; \tilde{v}(\mathrm{~K} \mathrm{Br}) /$ $\mathrm{cm}^{-1} 1602(\mathrm{C}=\mathrm{N})$ and 1418 (acac); m/z 683 (M - acac).

[Fe ${ }^{\prime \prime \prime} L^{1}$ (acac)] 4. A mixture of $\mathrm{H}_{2} \mathrm{~L}^{1}(0.5 \mathrm{~g}, 0.8 \mathrm{mmol})$ and [F e(acac $)_{3}$ ] $(0.28 \mathrm{~g}, 0.8 \mathrm{mmol})$ in acetonitrile $\left(30 \mathrm{~cm}^{3}\right)$ was 
refluxed for $6 \mathrm{~h}$. The resultant solution was filtered and concentrated, and dark red crystals were obtained upon standing for $1 \mathrm{~d}$. Y ield $0.52 \mathrm{~g}, 83 \%$ (Found: $\mathrm{C}, 59.7 ; \mathrm{H}, 3.4 ; \mathrm{N}, 3.6$. $\mathrm{C}_{39} \mathrm{H}_{25} \mathrm{Cl}_{4} \mathrm{FeN}_{2} \mathrm{O}_{4}$ requires $\left.\mathrm{C}, 59.8 ; \mathrm{H}, 3.2 ; \mathrm{N}, 3.6 \%\right) ; \lambda_{\text {max }}$ $\left(\mathrm{CH}_{2} \mathrm{Cl}_{2}\right) / \mathrm{nm} 269$ ( $\varepsilon$ 75760), 360 (14960) and 445 (9020 dm $\left.\mathrm{mol}^{-1} \mathrm{~cm}^{-1}\right) ; \tilde{v}(\mathrm{~K} \mathrm{Br}) / \mathrm{cm}^{-1} 1604(\mathrm{C}=\mathrm{N})$ and 1424 (acac); m/z 684 (M - acac).

\section{$\mathrm{X}-\mathrm{R}$ ay crystallography}

Crystal data for complexes $3 \cdot \mathrm{CH}_{2} \mathrm{Cl}_{2}$ and $\mathbf{4} \cdot 2 \mathrm{H}_{2} \mathrm{O}$ are collected in Table 1. For $3 \cdot \mathrm{CH}_{2} \mathrm{Cl}_{2}$ a green crystal of dimensions $0.25 \times 0.50 \times 0.50 \mathrm{~mm}$ was used for data collection at $25^{\circ} \mathrm{C}$ on a Enraf- $\mathrm{N}$ onius diffractometer (graphite-monochromatized $\mathrm{Cu}$ radiation, $\lambda=1.5406 \AA$ ) using $\theta-2 \theta$ scans. Intensity data $\left(2 \theta_{\max }=130^{\circ} ; \mathrm{h}-16\right.$ to $16, \mathrm{k} 0$ to $21, \mathrm{I} 0$ to 18 ; three standard reflections measured every $3600 \mathrm{~s}$ showed $2 \%$ decay) were corrected for decay and for Lorentz-polarisation effects and an empirical absorption correction was made. $6513 \mathrm{U}$ nique reflections were obtained from a total of 6613 measured reflections; 3592 reflections with $I>2 \sigma(I)$ were used in the structural analysis. The structure was solved by Patterson and Fourier methods ${ }^{10}$ and subsequent refinement by full-matrix least squares was performed using the software package N RCVA X .11 All 53 non-H atoms were refined anisotropically. Convergence for 476 variable parameters by least-squares refinement was reached at $R=0.077$ and $R^{\prime}=0.087$ with a goodness of fit of $2.17,(\Delta / \sigma)_{\max }=0.01$. The final Fourier-difference map was featureless, with residual extrema of 0.89 and -0.67 e $\AA^{-3}$ respectively.

For complex $4 \cdot 2 \mathrm{H}_{2} \mathrm{O}$ a purple-brown crystal of dimensions $0.20 \times 0.15 \times 0.35 \mathrm{~mm}$ was used for data collection at $25^{\circ} \mathrm{C}$ on a Enraf-N onius diffractometer (graphite-monochromatized M o- $\mathrm{K} \alpha$ radiation, $\lambda=0.7107 \AA$ ) using $\omega-2 \theta$ scans. Intensity data $\left(2 \theta_{\max }=44^{\circ}\right.$; h 0 to $12, \mathrm{k}-18$ to $18, \mathrm{I}-21$ to 21 ; three standard reflections measured every 300 showed decay of $7.95 \%)$ were corrected for decay and for L orentz-polarisation effects and an empirical absorption correction was made. 9397 U nique reflections were obtained from a total of 9972 measured reflections; 5494 reflections with I $>3 \sigma($ I) were used in the structural analysis. The structure was solved by direct methods (SIR $92^{12}$ ), expanded by the F ourier method and refined by fullmatrix least squares using the software package TEX SAN. ${ }^{13}$ Two formula units constitute a crystallographic asymmetric unit. All $100 \mathrm{non}-\mathrm{H}$ atoms, including the oxygen atoms of the four water molecules, were refined anisotropically. Hydrogen atoms of the water molecules were not located. C onvergence for 937 variable parameters by least-squares refinement was reached at $R=0.045$ and $R^{\prime}=0.050$ with a goodness of fit of 2.07, $(\Delta / \sigma)_{\max }=0.04$. The final Fourier-difference map was featureless, with residual extrema of 0.80 and -0.45 e $\AA^{-3}$ respectively.

CCD C reference number 186/632.

\section{Alkene oxidation}

All catalytic oxidation reactions were carried out at room temperature under an argon atmosphere unless specified. In a typical run the alkene $(100 \mathrm{mg})$, catalyst $(5 \mathrm{mg})$ and $\mathrm{Phl} O$ (50 $\mathrm{mg}$ ) were stirred in the appropriate solvent $\left(5 \mathrm{~cm}^{3}\right)$ until all PhlO had dissolved. The epoxide product and iodobenzene formed were quantified by GC using the internal standard method and the epoxide yield for the PhlO epoxidation was based on the amount of iodobenzene formed.

\section{R esults and $D$ iscussion}

Previous studies by $M$ eunier and co-workers ${ }^{5}$ demonstrated that Schiff bases can readily form complexes with transition-metal ions in alcohol. Despite this, we found that the catalytically inactive $\left[\mathrm{M} \mathrm{n}^{\mathrm{III}}{ }_{2} \mathrm{~L}{ }_{2}^{1}(\mathrm{OM} \mathrm{e})_{2}\right]$ dimer was afforded by

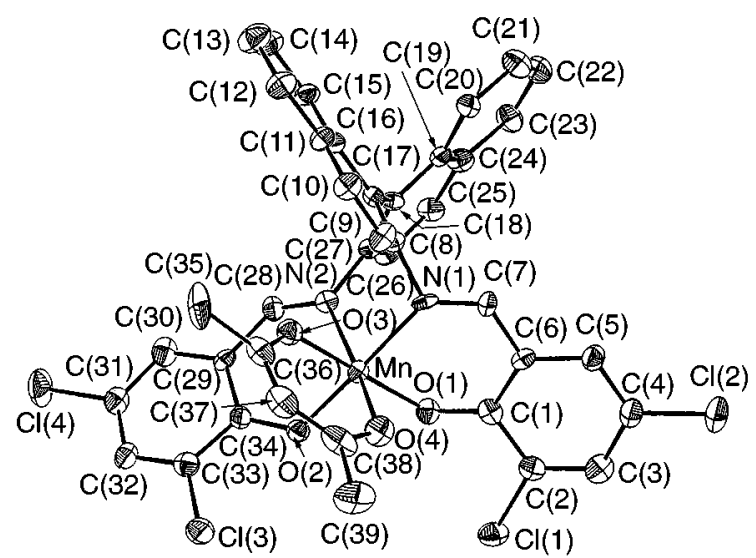

Fig. 1 Perspective view of one enantiomer of complex $\mathbf{3} \cdot \mathrm{CH}_{2} \mathrm{Cl}_{\mathbf{2}}(30 \%$ probability ellipsoids, solvent molecule omitted)

refluxing the binaphthyl Schiff base with $\mathrm{Mn}\left(\mathrm{O}_{2} \mathrm{CMe}\right)_{3}$ in methanol. ${ }^{4}$

Subsequently, by using acetonitrile as solvent and hence removing the methoxide ions, we have been able to prepare monomeric binaphthyl Schiff-base complexes. H ence treatment of $\mathrm{M} \mathrm{n}\left(\mathrm{O}_{2} \mathrm{CM} \mathrm{e}\right)_{3}$ with $\mathrm{H}_{2} \mathrm{~L}^{1}$ and $\mathrm{H}_{2} \mathrm{~L}^{2}$ in acetonitrile yielded [M n'"' $\left.\mathrm{L}^{1}\left(\mathrm{O}_{2} \mathrm{CM} \mathrm{e}\right)\right] 1$ and [M $\mathrm{n}^{\prime \prime \prime} \mathrm{L}^{2}\left(\mathrm{O}_{2} \mathrm{CM}\right.$ e) $] 2$ as dark green solids respectively. In solution, complexes $\mathbf{1}$ and $\mathbf{2}$ are stable for $2 \mathrm{~h}$ at room temperature, but slow decomposition is observed over longer periods. By comparison, reaction of [M n(acac $)_{3}$ ] and [ $\left.\mathrm{Fe}(\mathrm{acac})_{3}\right]$ with $\mathrm{H}_{2} \mathrm{~L}^{1}$ in acetonitrile afforded $\left[M n^{\prime \prime \prime} L^{1}(\mathrm{acac})\right] 3$ and $\left[\mathrm{F} \mathrm{e}^{\prime \prime \prime} \mathrm{L}^{1}(\mathrm{acac})\right] \mathbf{4}$ respectively, which are stable in solution for over $24 \mathrm{~h}$. This difference may be attributed to the strained nature of the four-membered ring formed between the metal ion and the bidentate acetato group in 1 and $\mathbf{2}$, while by analogy a six-membered ring is present in $\mathbf{3}$ and $\mathbf{4}$. The U V/VIS spectra of $\mathbf{1}$ and $\mathbf{3}$ are comparable indicating that the complexes are structurally related.

\section{C rystal structures of binaphthyl Schiff-base complexes}

The different chiral modes of ligation by the tetradentateligand in an octahedral complex are shown in $\mathrm{F}$ ig. 3. The remaining sites are cis, while $\alpha$ and $\beta$ denotes trans- and cis-aryloxide groups respectively; $\Delta$ chirality at the metal atom arises from co-ordination by an ( $R$ )-ligand, and the $\Lambda$ form is generated upon complexation by an (S)-ligand.

$\mathrm{M}$ olecular structures of the racemic complexes $3 \cdot \mathrm{CH}_{2} \mathrm{Cl}_{2}$ and $4 \cdot 2 \mathrm{H}_{2} \mathrm{O}$ have been established by $\mathrm{X}$-ray crystallography. The geometry around the manganese atom in $3 \cdot \mathrm{CH}_{2} \mathrm{Cl}_{2}(\mathrm{Fig} .1)$ is octahedral with the Schiff-base ligand bound to the metal centre in a cis- $\beta$ configuration. The acac ligand occupies the remaining co-ordination sites with $\mathrm{Mn}-\mathrm{O}(3)$ and $\mathrm{Mn}-\mathrm{O}$ (4) distances of $1.915(7)$ and $2.124(7) \AA$ respectively. The dihedral angle of $85.5(3)^{\circ}$ between the two naphthalene rings is similar to those of 75.5(1) and $87.59(5)^{\circ}$ in $\left[\mathrm{Cu}^{\prime \prime} \mathrm{L}^{1}\right]^{4}$ and $2,2^{\prime}-$ bis(pyridine-2-carboxamido)-1,1'-binaphthyl. ${ }^{14}$ As expected, the (S)-binaphthyl Schiff-base ligand induces a chiral centre $(\Lambda)$ at the manganese atom while the $(\mathrm{R})$ form affords $\Delta$ chirality at the metal. Complex $4 \cdot 2 \mathrm{H}_{2} \mathrm{O}$ (Fig. 2) is isostructural to 3. $\mathrm{CH}_{2} \mathrm{Cl}_{2}$ hence the corresponding dihedral angle of $72.1(1)^{\circ}$ is comparable. All metal-ligand bond lengths are slightly longer due to the greater radius of the iron(III) ion.

\section{C atalytic epoxidation of alkenes using PhIO}

We have previously demonstrated that the in situ $\mathrm{M} \mathrm{n}^{\mathrm{III}}+(\mathrm{S})$ $\mathrm{H}_{2} \mathrm{~L}$ system can catalyse asymmetric epoxidation of alkenes using PhlO with moderate e. $\mathrm{e}^{4} \mathrm{H}$ owever, there are potential problems associated with in situ catalysis: complexation is not well defined and may be incomplete, greater than one active species may be present and the choice of solvents is limited to 


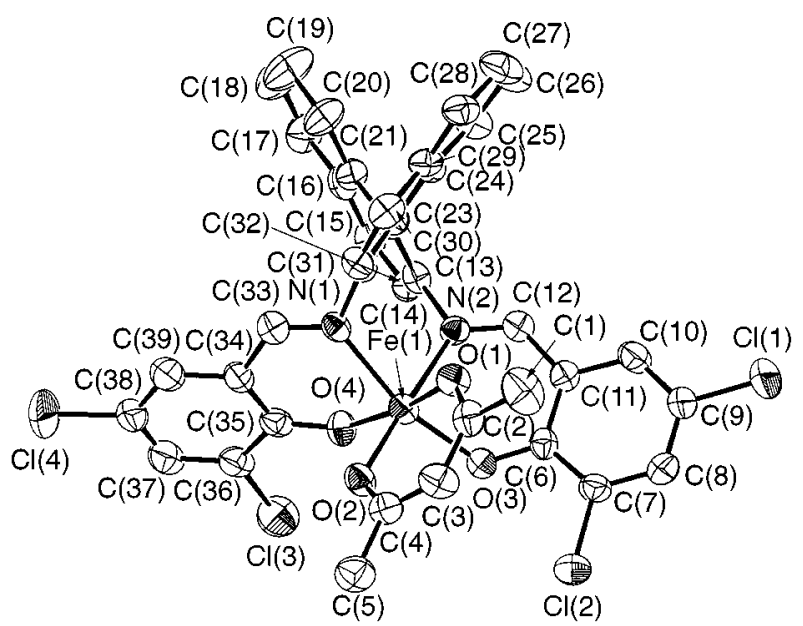

Fig. 2 Perspective view of one enantiomer of complex $4 \cdot 2 \mathrm{H}_{2} \mathrm{O}$ [M olecule A, $40 \%$ probability ellipsoids, solvent molecules omitted, $\mathrm{C}(22)$ is obscured by $\mathrm{C}(30)]$

those which can solubilise the reactants. We therefore investigated the catalytic reactivity of the isolated chiral Schiff-base manganese complexes using an analogous procedure and found that they are also active towards asymmetric alkene epoxidation by PhIO. The reactivity of (R)-1 and (R)-2 and their respective yields and e.e. for the epoxidation of styrene are very similar to those for the corresponding in situ systems under identical conditions, which implies that the catalytic cycle of the latter proceeds by generating the monomeric species isolated in this work.

For the present study attention was focused on complex (R )-2 since the in situ system bearing the same ethyl/nitro substituents

Table 1 Crystal data for complexes $3 \cdot \mathrm{CH}_{2} \mathrm{Cl}_{2}$ and $\mathbf{4} \cdot 2 \mathrm{H}_{2} \mathrm{O}$

\begin{tabular}{|c|c|c|}
\hline & 3. $\mathrm{CH}_{2} \mathrm{Cl}_{2}$ & $4 \cdot 2 \mathrm{H}_{2} \mathrm{O}$ \\
\hline Formula & $\mathrm{C}_{39} \mathrm{H}_{25} \mathrm{Cl}_{4} \mathrm{M} \mathrm{nN}_{2} \mathrm{O}_{4} \cdot \mathrm{CH}_{2} \mathrm{Cl}_{2}$ & $\mathrm{C}_{39} \mathrm{H}_{25} \mathrm{Cl}_{4} \mathrm{FeN}_{2} \mathrm{O}_{4} \cdot 2 \mathrm{H}_{2} \mathrm{O}$ \\
\hline $\begin{array}{l}\text { M } \\
\text { Crystal system }\end{array}$ & M onoclinic & $\begin{array}{l}819.33 \\
\text { Triclinic }\end{array}$ \\
\hline $\begin{array}{l}\text { Crystal system } \\
\text { Space group }\end{array}$ & $P 2_{1} / c$ & $\mathrm{P} \overline{1}($ no. 2$)$ \\
\hline $\mathrm{a} / \AA$ & $13.974(6)$ & $11.664(2)$ \\
\hline $\mathrm{b} / \AA \AA \AA$ & $18.036(8)$ & $17.550(4)$ \\
\hline & $15.5367(17)$ & $20.876(4)$ \\
\hline$\alpha /^{\circ}$ & & $66.00(2)$ \\
\hline$\beta /^{\circ}$ & $100.193(24)$ & $80.09(1)$ \\
\hline$\gamma /{ }^{\circ}$ & & $84.87(2)$ \\
\hline$\cup / \AA^{3}$ & $3854.1(24)$ & $3503(1)$ \\
\hline & & 4 \\
\hline$D_{c} / g ~ c m^{-3}$ & 1.495 & 1.415 \\
\hline$\mu / \mathrm{cm}^{-1}$ & 70.9 & 7.17 \\
\hline $\mathrm{F}(000)$ & 1760 & 1676 \\
\hline & $0.077,0.087$ & $0.045,0.050$ \\
\hline
\end{tabular}
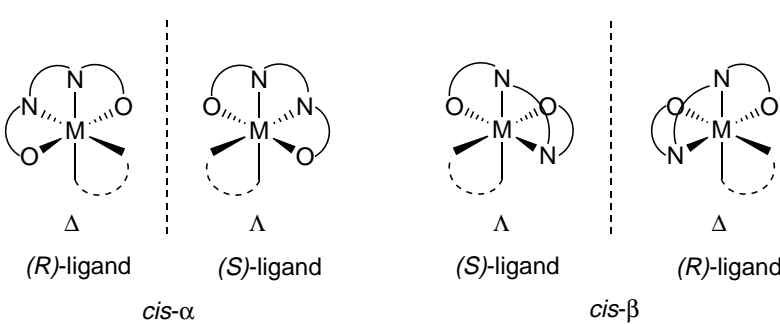

$\Delta$

(S)-ligand

(R)-ligand

Fig. 3 Chiral centres in binaphthyl Schiff-base complexes

gave the highest e.e. of $58 \%$ and cis:trans ratio of $10: 1$ for the epoxidation of cis- $\beta$-methylstyrene. ${ }^{4}$ R esults are summarised in Table 4: significantly, the enantioselectivity is enhanced by using a low-polarity solvent, e.g. benzene and toluene and at lower temperatures. This also suppresses the cis/trans isomerisation of cis-disubstituted alkenes. The effect of solvents upon ee. has recently been observed for epoxidation catalysts based on ruthenium porphyrins. ${ }^{15} \mathrm{H}$ ence the epoxidation of cis- $\beta$ methylstyrene in toluene gave e.e. of $63 \%$ at $25^{\circ} \mathrm{C}$ and $76 \%$ at $-20{ }^{\circ} \mathrm{C}$. A cis: trans ratio of $14: 1$ was obtained at $25^{\circ} \mathrm{C}$, while only a trace amount of the trans product was afforded at $-20^{\circ} \mathrm{C}$. L owering the reaction temperature to $-20^{\circ} \mathrm{C}$ did not affect the yield markedly, although at $-60^{\circ} \mathrm{C}$ virtually no epoxidation reaction was observed.

The acac derivative (R )-3 is also active towards the epoxidation of alkenes, although slightly lower yields and e.e. were detected compared to (R)-1. For example, an e.e./yield of $43 \% / 72 \%$ for (R ) -3 and $54 \% / 80 \%$ for (R )-1 were obtained using cis- $\beta$-methylstyrene. The active species for the epoxidation reaction may be an oxo-intermediate, ${ }^{2}$ or a PhIO adduct in accordance with the study by $\mathrm{H}$ ill and co-workers ${ }^{16}$ on the $\mathrm{M} \mathrm{n}$ (tpp) system $\left(\mathrm{H}_{2} \mathrm{tpp}=5,10,15,20\right.$-tetraphenylporphyrin $)$ and work by $\mathrm{Valentine}$ and co-workers. ${ }^{17} \mathrm{~N}$ evertheless, since there is no direct evidence for the formation of such species and their

Table 2 Selected bond distances $(\AA)$ and angles $\left(^{\circ}\right)$ for complex $3 \cdot \mathrm{CH}_{2} \mathrm{Cl}_{2}$

$\begin{array}{lrlr}\mathrm{M} \mathrm{n}-\mathrm{O}(1) & 1.896(7) & \mathrm{M} \mathrm{n}-\mathrm{N}(2) & 2.277(7) \\ \mathrm{M} \mathrm{n}-\mathrm{O}(2) & 1.887(6) & \mathrm{N}(1)-\mathrm{C}(7) & 1.276(12) \\ \mathrm{M} \mathrm{n}-\mathrm{O}(3) & 1.915(7) & \mathrm{N}(1)-\mathrm{C}(8) & 1.444(12) \\ \mathrm{M} \mathrm{n}-\mathrm{O}(4) & 2.124(7) & \mathrm{N}(2)-\mathrm{C}(27) & 1.447(12) \\ \mathrm{M} \mathrm{n}-\mathrm{N}(1) & 2.056(8) & \mathrm{N}(2)-\mathrm{C}(28) & 1.275(12) \\ & & & \\ \mathrm{O}(1)-\mathrm{M} \mathrm{n}-\mathrm{O}(2) & 90.9(3) & \mathrm{O}(2)-\mathrm{M} \mathrm{n}-\mathrm{N}(2) & 86.9(3) \\ \mathrm{O}(1)-\mathrm{M} \mathrm{n}-\mathrm{O}(3) & 178.2(3) & \mathrm{O}(3)-\mathrm{M} \mathrm{n}-\mathrm{O}(4) & 87.5(3) \\ \mathrm{O}(1)-\mathrm{M} \mathrm{n}-\mathrm{O}(4) & 91.0(3) & \mathrm{O}(3)-\mathrm{M} \mathrm{n}-\mathrm{N}(1) & 92.0(3) \\ \mathrm{O}(1)-\mathrm{M} \mathrm{n}-\mathrm{N}(1) & 87.0(3) & \mathrm{O}(3)-\mathrm{M} \mathrm{n}-\mathrm{N}(2) & 84.9(3) \\ \mathrm{O}(1)-\mathrm{M} \mathrm{n}-\mathrm{N}(2) & 96.5(3) & \mathrm{O}(4)-\mathrm{M} \mathrm{n}-\mathrm{N}(1) & 93.3(3) \\ \mathrm{O}(2)-\mathrm{M} \mathrm{n}-\mathrm{O}(3) & 90.3(3) & \mathrm{O}(4)-\mathrm{M} \mathrm{n}-\mathrm{N}(2) & 172.3(3) \\ \mathrm{O}(2)-\mathrm{M} \mathrm{n}-\mathrm{O}(4) & 94.7(3) & \mathrm{N}(1)-\mathrm{M} \mathrm{n}-\mathrm{N}(2) & 85.5(3) \\ \mathrm{O}(2)-\mathrm{M} \mathrm{n}-\mathrm{N}(1) & 171.8(3) & & \end{array}$

Table 3 Selected bond distances $(\AA)$ and angles $\left({ }^{\circ}\right)$ for molecule $A$ of complex $4 \cdot 2 \mathrm{H}_{2} \mathrm{O}$; parameters for molecule $B$ in square brackets

$\begin{array}{lr}\mathrm{Fe}(1)-\mathrm{N}(2) & 2.149(5)[2.144(5)] \\ \mathrm{N}(1)-\mathrm{C}(32) & 1.442(7)[1.442(7)] \\ \mathrm{N}(1)-\mathrm{C}(33) & 1.278(7)[1.277(7)] \\ \mathrm{N}(2)-\mathrm{C}(12) & 1.276(7)[1.276(7)] \\ \mathrm{N}(2)-\mathrm{C}(13) & 1.442(7)[1.446(8)] \\ & \\ \mathrm{O}(2)-\mathrm{Fe}(1)-\mathrm{N}(2) & 175.8(2)[174.4(2)] \\ \mathrm{O}(3)-\mathrm{Fe}(1)-\mathrm{O}(4) & 103.1(2)[101.8(2)] \\ \mathrm{O}(3)-\mathrm{Fe}(1)-\mathrm{N}(1) & 165.2(2)[165.6(2)] \\ \mathrm{O}(3)-\mathrm{Fe}(1)-\mathrm{N}(2) & 84.2(2)[84.0(2)] \\ \mathrm{O}(4)-\mathrm{Fe}(1)-\mathrm{N}(1) & 85.2(2)[84.8(2)] \\ \mathrm{O}(4)-\mathrm{Fe}(1)-\mathrm{N}(2) & 94.5(2)[94.6(2)] \\ \mathrm{N}(1)-\mathrm{Fe}(1)-\mathrm{N}(2) & 82.9(2)[82.7(2)]\end{array}$


Table 4 A lkene epoxidation catalysed by complex (R)-2 using PhlO

\begin{tabular}{|c|c|c|c|c|c|}
\hline \multirow[b]{3}{*}{ Substrate } & \multirow[b]{3}{*}{ Product } & \multicolumn{4}{|l|}{$e^{a} e^{a}(\%)$} \\
\hline & & \multirow{2}{*}{$\begin{array}{l}\text { Benzene } \\
25^{\circ} \mathrm{C}^{\mathrm{b}}\end{array}$} & \multicolumn{3}{|l|}{ Toluene } \\
\hline & & & $25^{b}$ & $0^{c}$ & $-20^{\circ} \mathrm{C}^{\mathrm{d}}$ \\
\hline $\begin{array}{l}\text { Styrene } \\
4-C \text { hlorostyrene } \\
\text { cis- } \beta \text {-M ethylstyrene }\end{array}$ & $\begin{array}{l}\text { Styrene oxide } \\
4-\text { Chlorostyrene oxide } \\
\text { cis- } \beta-M \text { ethylstyrene oxide }\end{array}$ & $\begin{array}{l}38(82) \\
38(91) \\
64(70)\end{array}$ & $\begin{array}{l}34(68) \\
36(65) \\
63(59)\end{array}$ & $\begin{array}{l}42(62) \\
43(63) \\
71(67)\end{array}$ & $\begin{array}{l}46(68) \\
46(64) \\
76(63)\end{array}$ \\
\hline
\end{tabular}

${ }^{a}$ Based on amount of Phl formed; yields (\%) in parentheses. ${ }^{b}$ Reaction for $0.5-1 \mathrm{~h} .{ }^{\mathrm{c}} \mathrm{R}$ eaction for $1-1.5 \mathrm{~h} .{ }^{\mathrm{d}} \mathrm{R}$ eaction for $3 \mathrm{~h}$. ${ }^{\mathrm{e}} \mathrm{R}$ configuration. ${ }^{\mathrm{f}}$ Benzaldehyde (2\%) was detected after each run. ${ }^{\mathrm{g}} 4$-Chlorobenzaldehyde (trace, except toluene, $25^{\circ} \mathrm{C}: 4 \%$ ) was detected after each run. ${ }^{\mathrm{h}} 1 \mathrm{R}, 2 \mathrm{~S}$ Configuration. trans- $\beta-M$ ethylstyrene oxide (benzene: $6 \%$; toluene, $25^{\circ} \mathrm{C}: 7 \% ; 0{ }^{\circ} \mathrm{C}$ and $-20^{\circ} \mathrm{C}$ : trace) was detected after each run.

isolation has so far been unsuccessful, the active species in this system remains a point of contention.

U nlike the manganese(III) catalysts, epoxidation of alkenes was not observed using the iron(III) complex (R)-4. A ddition of $\mathrm{Phl} O$ to a solution of (R)-4 led to rapid decomposition of the metal species.

\section{Conclusion}

New monomeric chiral binaphthyl Schiff-base complexes of manganese and iron have been prepared using acetonitrile as solvent. The manganese(III) derivatives (R)-1 to $\mathbf{3}$ mediate the catalytic asymmetric epoxidation of alkenes by $\mathrm{PhlO}$ and the highest e.e in this system so far has been achieved at $-20^{\circ} \mathrm{C}$ in low-polarity toluene. In contrast to the planar structures observed for Jacobsen-type catalysts, ${ }^{18}$ the crystal structures of the racemic complexes $3 \cdot \mathrm{CH}_{2} \mathrm{Cl}_{2}$ and $\mathbf{4} \cdot 2 \mathrm{H}_{2} \mathrm{O}$ depict non-planar molecules. This fundamental difference may be responsible for the higher e.e. obtained by Jacobsen, since in our system the environment for metal-alkene interaction is evidently more open, and this may ultimately lead to different reaction patterns.

\section{Acknowledgements}

We acknowledge support from The U niversity of $\mathrm{H}$ ong $\mathrm{K}$ ong and the Hong $\mathrm{K}$ ong Research $\mathrm{G}$ rants $\mathrm{C}$ ouncil.

\section{R eferences}

1 T. K atsuki and K. B. Sharpless, J. A m. Chem. Soc., 1980, 102, 5974; M. G. Finn and K. B. Sharpless, A symmetric Synthesis, ed J. D. M orrison, A cademic Press, N ew York, 1985, vol. 5, p. 247; H. C. Kolb, M. S. Van N ieuwenhze and K. B. Sharpless, Chem. R ev., 1995, 94, 2483 and refs. therein.

2 E. N. Jacobsen, Catalytic A symmetric Synthesis, ed. I. Ojima, VCH, $\mathrm{N}$ ew York, 1993, p. 159; T. K atsuki, Coord. Chem. Rev., 1995, 140, 189.
3 C. Rosini, L. Franzini, A . R affaelli and P. Salvadori, Synthesis, 1992, 504; R. N oyori, Chem. Soc. Rev., 1989, 18, 187; R. N oyori and H. Takaya, Acc. Chem. Res., 1990, 23, 345 and refs. therein.

4 C. W. H O, W. C. Cheng, M. C. Cheng, S. M. Peng, K. F. Cheng and C. M. Che, J. Chem. Soc., Dalton Trans., 1996, 405.

5 K . Bernardo, S. Lippard, A. Robert, G. Commenges, F. D ahan and B. M eunier, Inorg. Chem., 1996, 35, 387.

$6 \mathrm{M}$. N. Bhattacharjee, M. K. Chaudhuri and D. T. K hathing, J. Chem. Soc., Dalton Trans., 1982, 669.

7 D. D. Perrin, W. L. F. A rmarego and D. R. Perrin, Purification of L aboratory Chemicals, 2nd, edn., Pergamon, Oxford, 1980.

8 H. L indler and R. D ubuis, O rg. Synth., 1973, Coll. Vol. V, 880.

$9 \mathrm{~L}$. F. Fieser and M. Fieser, Reagents for O rganic Synthesis, Wiley, N ew York, 1967, vol. 1, p. 137

10 PATTY and DIRDIF 92, P. T. Beurskens, G. Admiraal, G. Beurskens, W. P. Bosman, S. Garcia-Granda, R. O. Gould, J. M. M. Smits and C. Smykalla, The DIRDIF program system, Technical Report of the Crystallography L aboratory, U niversity of Nijmegen, 1992.

11 N RCVAX, E. J. Cabe, Y. Le Page, J. P. Charland, F. L. Lee and P. S. White, J. A ppl. Crystallogr., 1989, 22, 384.

12 SIR 92, A. A Itomare, M. Cascarano, C. G iacovazzo, A. Guagliardi, M . C. Burla, G. Polidori and M . Camalli, J. A ppl. Crystallogr., 1994, 27, 435.

13 TEXSAN, Crystal Structure A nalysis Package, Molecular Corporation, H ouston, TX, 1985 and 1992.

14 J. H. Lin, C. M. Che, T. F. Lai, C. K. Poon and Y. X. Cui, J. Chem. Soc., Chem. Commun., 1991, 468.

15 Z. G ross, S. Ini, M. K apon and S. Cohen, Tetrahedron L ett., 1996, $37,7325$.

16 J. A. Smegal, B. C. Schardt and C. L. H ill, J. A m. Chem. Soc., 1983, 105, 3510; J. A. Smegal and C. L. H ill, J. A m. Chem. Soc., 1983, 105, 3515.

17 R. B. Van Atta, C. C. Franklin and J. S. Valentine, Inorg. Chem., 1984, 23, 4121.

18 W. Zhang, J. L. L oebach, S. R. Wilson and E. N. Jacobsen, J. A m. Chem. Soc., 1990, 112, 2801; P. J. Pospisil, D. H. Carsten and E. N. Jacobsen, Chem. Eur. J., 1996, 2, 974.

Received 30th J anuary 1997; Paper 7/00712D 